\title{
Analyzing the Views of Teachers and Prospective Teachers on Information and Communication Technology via Descriptive Data Mining
}

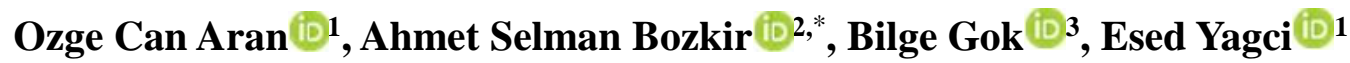

\author{
${ }^{1}$ Hacettepe University, Department of Educational Science, Ankara, Turkey \\ ${ }^{2}$ Hacettepe University, Department of Computer Engineering, Ankara, Turkey \\ ${ }^{3}$ Hacettepe University, Department of Primary Education, Ankara, Turkey
}

\section{ARTICLE HISTORY}

Received: 07 March 2019

Revised: 23 May 2019

Accepted: 20 June 2019

\section{KEYWORDS}

Communication technology,

Data mining,

Teachers,

Prospective teachers, Clustering

\begin{abstract}
This study aims to determine the overt and covert patterns that teachers' and prospective teachers' views on the use of information and communication technology (ICT) instruments contain by using the method of data mining. The study group was composed of 192 prospective teachers attending a state university in Ankara, Turkey and 101 teachers working in Ankara-all of whom took part in the study on the basis of volunteering. Teachers' and prospective teachers' views were obtained by means of a scale. Clustering and association rules - algorithms for data mining - were applied to the data collected, and thus the frequently held patterns for teachers' and prospective teachers' views on ICT instruments were found. Consequently, cluster analysis suggested that prospective teachers considered themselves more competent than teachers in terms of computer skills but that teachers were the group having the most positive views. In addition to this, the results of association rules analysis indicated that the prospective teachers and teachers held the opinion that ICT instruments added variety to the teaching-learning process and ensured students' focusing their attention on lessons, also stated that using ICT instruments would increase students' participation in classes.
\end{abstract}

\section{INTRODUCTION}

The skill of using technology, one the most important skills of twenty-first century $(\mathrm{P} 21,2019)$ is becoming more and more important day by day (Baytekin, 2004). Technology promotes the improvement of students' self-regulation and higher order thinking skills and thus it is considered as an effective instrument forming the basis of student-centered learning (Haşlaman, Kuşkaya Mumcu, \& Usluel, 2007; Kottler \& Brookhart Costa, 2009). Also technology is as important as the disciplines of science and mathematics in raising researchers, educators and leaders who can solve problems encountered in daily life and who can think in depth (STEM, 2019). Curricula are of great importance in this respect in raising technology literate individuals who can adapt to the requirements of the age (Yanpar, 2005). Employing technological support in implementing curricula will ensure that many students understand a subject in depth (Can Aran \& Senemoğlu,

CONTACT: Ahmet Selman Bozkir $₫$ selman@cs.hacettepe.edu.tr Computer Engineering, Ankara, Turkey 
2014) because technology-assisted education makes it possible to enrich learning environments with different activities. A teacher teaching the unit of living things in Life Studies course, for example, can present the geographical and biological properties of living organisms to their students by using sounds, pictures and graphs by means of technology (Yanpar Yelken, 2012). In history classes, on the other hand, students can research the causes of First World War on the internet. Students can also travel in space in technological environment and investigate planets while learning about the solar system. Students studying architecture at university, for instance, can furnish rooms according to the size of the rooms by using technology while decorating the house (Anthony, 2012). Enriching learning environments with technology assistance and with different activities will ensure retention in learning (Akkoyunlu \& Y1lmaz, 2005; Kürüm, 2016) and thus it will affect students' achievement in positive ways (Yanpar Yelken, 2012).

Using the technology effectively is highly important for technology-assisted education to attain success (Karaman \& Kurfallı, 2008; Borich, 2014). Being knowledgeable about technology can be regarded as a part of teaching it. Yet, knowledge of technology on its own is not sufficient to teach technology (Bybee \& Loucks-Horsley, 2000; Usluel \& Aşkar, 2003). The reason for this is that teachers need to know first how to use technology and then how to integrate technology into their classes so that they can use technology effectively in their classes (Sert, Kurtoğlu, Akıncı, \& Seferoğlu, 2012). It is commonly thought that technology cannot improve badly planned teaching and that teachers' skill in including technology in their teaching is important in order for technology to be influential in teaching (Borich, 2014). In this respect, technological literacy is an important quality for teachers to possess (Çağıltay, Çakıroğlu, Çağıltay, \& Çakıroğlu, 2001; Bayazıt \& Seferoğlu, 2009).

Research demonstrates that teachers who have positive attitudes towards Information and Communication Technology (ICT) integrate it more into their teaching practice (Moseley et al., 1999; Mümtaz, 2000). Additionally, some research studies point out that teachers who have computers and internet connection at home and in the classroom -that is to say, their knowledge of technology use - use technology more (Varner, 2003; Karaman \& Kurfall1, 2008). However, other research studies find out that elementary or secondary school teachers do not use technology sufficiently (Çağıltay et al., 2001; Kurtdede Fidan, 2008). Research has found that teachers' reasons for not using computers included problems in access to computers and low level computer skills (Mümtaz, 2000; Jenson, Lewis, \& Smith, 2002; Buabeng-Andoh, 2012).

Efforts to improve physical conditions to support the use of technology are continuing today. Besides, more and more emphasis is laid to technology in curricula. Even if curricula facilitate the use of technology, improving those skills of teachers during pre-service training is very important (Wicklein, 1993; Yanpar, 2005). Therefore, including activities improving those skills in teacher training programmes assures that teachers become well-equipped with knowledge of technology in their training (Bayazıt \& Seferoğlu, 2009). Prospective teachers' views in relation to ICT are considered important in including ICT in the process of teaching (Can Aran, Derman, \& Yağc1, 2016). Review of literature indicates that prospective teachers use information technologies more than teachers do (Seferoğlu, Akbıyık, \& Bulut, 2008). In comparing computer using skills of new teachers with those of experienced teachers, however, it was found that new teachers felt more comfortable in using computers than experienced teachers and that they used computers more often in lesson preparation (Russell, Bebell, O'Dwyer, \& O'Connor, 2003). On examining prospective teachers' attitudes towards computers, studies found that there were positive correlations between their skills in using computers and having a computer (Deniz \& Köse, 2003). In addition to that, positive correlations were also found between having a computer and being computer literate (Kıyıc1, 2008). Despite this, Çavuş and Gökdaş (2006) concluded that prospective teachers' levels of using computers were low. Besides, technology is considered a gender-specific issue related to men (Lewis, 1999; Kuşkaya Mumcu \& Koçak Usluel, 2004; 
Çoklar, 2008). However there are also studies in the literature demonstrating that whether or not teachers and prospective teachers use computers in their classes does not cause a difference in terms of gender (Hill Less, 2003; Deniz \& Köse, 2003; Gerçek, Köseoğlu, Yılmaz, \& Soran, 2006; Çoklar, 2008). Considering the differences in the conclusions of research studies, it is given priority to investigating technology in terms of gender as Lewis (1999) emphasized. Therefore, the literature review shows that the use of technology can be explained with lots of variables and that teachers' positive views on the use of technology in teaching-learning processes will make teaching environments more effective. This study aims to describe various characteristics of teachers and prospective teachers and to reveal their views concerning the use of technology in classroom settings. This study analyzes various characteristics and views of teachers and prospective teachers via data mining and reveals the internal patterns along with contributing to the literature.

\section{METHOD}

This study aims to determine the overt and covert patterns that teachers' and prospective teachers' views on the use of information and communication technology (ICT) instruments Thus, the study used a descriptive method so as to reveal the existing situation.

\subsection{Population and Sample Selection}

The study group was composed of 192 university students attending the educational faculty of a state university in Ankara and 101 teachers working in Ankara selected on a voluntary basis. Teachers' and prospective teachers' views were obtained by means of a questionnaire. Clustering and association rules- algorithms for data mining- were applied to the data collected, and thus the frequently held patterns for teachers' and prospective teachers' views on ICT instruments were found.

\subsection{Data Collection}

In this study, an ICT scale developed by the researchers, was used. The pilot form of the ICT scale had the 24-item and it was conducted to 172 undergraduate students attending various departments of the educational faculty of Hacettepe University. Then, factor analysis was conducted for the data obtained from pilot form so as to test the construct validity of the scale. The data obtained for this purpose were exposed to factor analysis. The Kaiser-Meyer-Olkin (KMO) test value for the fit of the data to the factor analysis was found as 0.80 and Barlett's sphericity test was found as $\left(\chi^{2}(105)=435.70, \mathrm{p}<0.01\right)$. These results showed that the data fit the factor analysis. 9 items having similar values (Floyd \& Widaman, 1995; Tabachnick \& Fidell, 2007) and having no loads above 0.30 in two factors were removed from the scale. Having removed the above mentioned 9 items, analyses were repeated so as to decide on the number of factors. Following exploratory factor analysis (EFA), it was found that the scale had two factors with eigenvalue bigger than 1 and that $45.08 \%$ of the total variance was explained. In one-factor scales, having $30 \%$ or more explained variance can be considered sufficient but in multi-factor scales the explained variance is expected to be higher (Büyüköztürk, 2006). On examining the factor loads in exploratory factor analysis, it was found that the factor loads were between 0.53 and 0.76 in the first factor and that they were between 0.59 and 0.78 in the second factor. An examination of the items showed that the 10 items in the first factor were related to the direct effects of ICT on students' learning while 5 items in the second factor related to the indirect effects of ICT on students' learning. Accordingly, the results of the analysis indicated that the scale was valid and reliable. The developed scale had 15 items in total. Cronbach's Alpha for the ultimate scale was found to be as .76. The items in the scale aiming to discover teachers' and prospective teachers' views on the use of ICT instruments were in 5-point Likert type. Additionally, demographic information was also included in the first part of the scale. This 
includes type of participant, gender, having taken a course related with ICT before, having a computer of one's own, computer using skills and length of computer use (daily).

\subsection{Data Analysis}

The methodology of data mining was employed in analyzing the research data. Data mining can be defined as the process of exploring meaningful knowledge within data sets by making use of such methodology as artificial intelligence, statistics and machine learning (Tan, Steinbach, \& Kumar, 2006). Data mining processes are divided into two categories as predictive and descriptive (Bozkir, Gok, \& Sezer, 2008). In predictive methods, the data labelled as numeric or discrete are divided into training, test and validation groups. The models to be created is trained by utilizing the training data in order to predict unseen test data. Various approaches (such as decision trees, support vector machines, statistics based naïve bayes and hidden Markov models) are suggested in this area in the literature.

Descriptive data mining, on the other hand, aims to uncover the hidden, meaningful and useful patterns in the data. Such methods as clustering and association rules mining come into prominence in the processes of descriptive data mining. The two most important elements distinguishing descriptive data mining from predictive data mining are as in the following: (1) aiming to uncover the hidden patterns in the data instead of predicting, and (2) conducting the processes based on unlabeled data and in unsupervised manner.

This study investigates the characteristics of teachers and prospective teachers and their views on the use of information and communication technology instruments by using clustering and association rules-which are among the methods of descriptive data mining. The analyses were carried out by using SPSS Clementine 12 data mining software. While K-means algorithm was used in clustering, the generalized rule induction (GRI) algorithm was used in finding the association patterns available in views concerning the items in the scale. The individuals answering the questionnaire were divided into 3 groups by means of clustering and the differences between the groups were analyzed; and frequently observed association patterns in teachers' and prospective teachers' views were uncovered through association rules. The analysis methods used in this study are described below.

\subsubsection{K-means Clustering}

Clustering, in simplest terms, is the process of grouping the elements in a data set according to their qualities. Even though humans manage to do the clustering according to a few qualities, it becomes more and more difficult for them to do this as the number of qualities increase (Bozkir, Gok, \& Sezer, 2009). Clustering methods have been used in innumerable areas (computer vision, geoscience, education, etc.) so far. Clustering is a useful method for the discovery of some knowledge from a dataset and an exploratory method for helping to solve classification problems (Kıray, Gok, \& Bozkir, 2015).

K-means clustering approach, in particular, is indeed an unsupervised machine learning method and it was suggested by MacQueen (1967). Accordingly, k amount of examples are selected randomly or with another approach from a sample. The selected examples are regarded as centroids and the other examples are assigned to the relevant sets according to their distance from the first selected centroids. Distance is calculated by considering the qualities that the examples have. Having done the first assigning process, centroids are updated by considering the newly assigned examples. Thus, centroids continuously change at smaller intervals. The process continues until the total change is set to zero.

In K-means clustering method, objective function $J$ minimises error squares as is seen in

Equation (1). Accordingly, $\left\|\mathrm{x}_{\mathrm{i}}^{(\mathrm{j})}-\mathrm{c}_{\mathrm{j}}\right\|^{2}$ is described as a distance function, $\mathrm{x}_{\mathrm{i}}^{(\mathrm{j})}$ is described as an 
example in the data, and, $\mathrm{c}_{\mathrm{j}}$ is described as $\mathrm{j}$ centroid; the objective function $J$ can be represented as in Equation (1).

$$
J=\sum_{\mathrm{j}=1}^{\mathrm{k}} \sum_{\mathrm{i}=1}^{\mathrm{n}}\left\|\mathrm{x}_{\mathrm{i}}^{(\mathrm{j})}-\mathrm{c}_{\mathrm{j}}\right\|^{2}
$$

The objective in cluster analysis is that sets have high intra-class similarities and low inter-class similarities- independently of the method (Tan, Steinbach and Kumar, 2006). The SPSS Clementine software enables users to construct their models in a visual environment by dragging and dropping appropriate nodes. This has been sometimes referred as visual data mining. In order to apply K-means clustering schema, we first loaded the data as from a Microsoft Excel file into SPSS Clementine 12 software. Following to pre-process stage (i.e. setting data types and filtering out the unnecessary variables) we have picked the K-means module from the toolbox and connected it to "Type" node as shown in Figure 1. For the next stage, we have selected algorithm parameters (i.e. cluster count) and made it run over the source data. Following to the completion of the process, we have analyzed and gathered the results sourced from the clustering study.

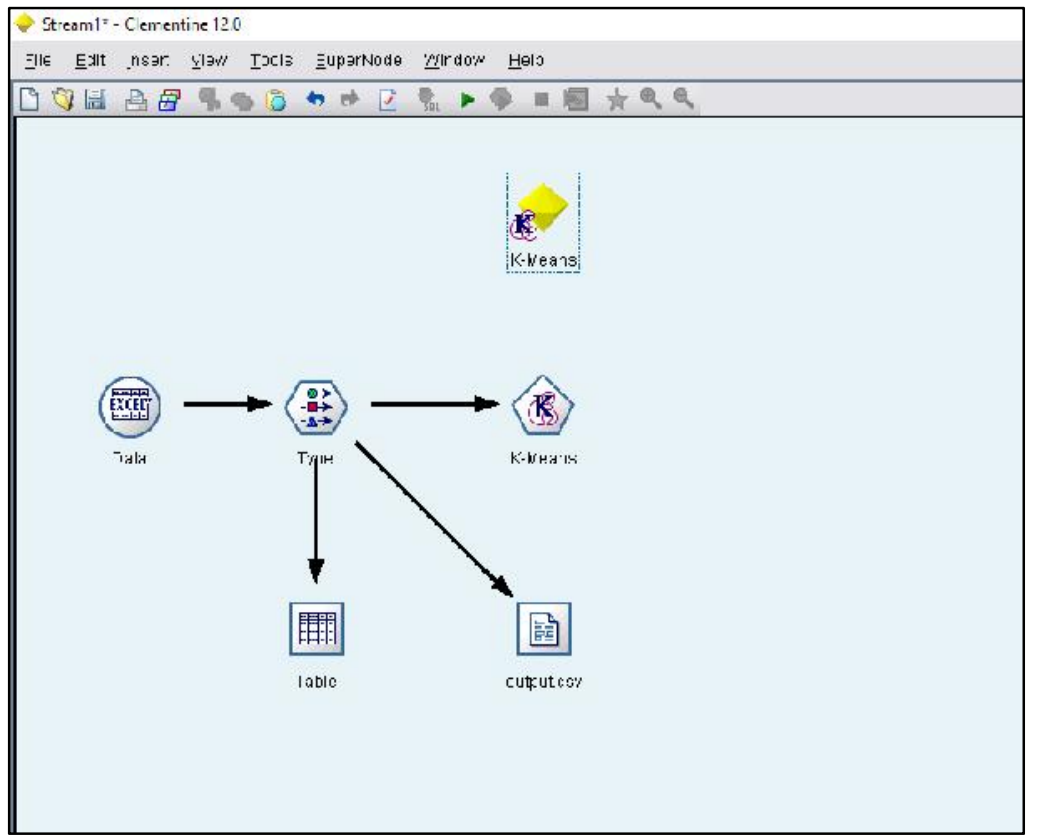

Figure 1. K-means clustering application in SPSS Clementine 12

\subsubsection{Association rules mining and GRI}

Association rules analysis - as a method of descriptive and unsupervised learning-based data mining - is a process of discovering hidden associations seen in activities, situations and observations in a data set according to relation and pattern associations. The method became popular with market basket application revealing what products customers buy in association with other products. Association rules analysis is also used today in such areas as medicine, education and engineering (Bozkir, Gok, \& Sezer, 2008). Agrawal and Srikant (1994) recommended Apriori algorithm which is the most commonly known algorithm in this field. Each transaction contains at least one component according to association rules analysis and Apriori algorithm (for instance, $t_{i}=\{$ apples, pears $\}$ ). In this way, each transaction will have one or more than one element. Apriori algorithm works at two stages. First, it determines frequent item sets and prunes the irrelevant item sets in a bottom-up approach. At this stage user should determine the minimum support (min-sup) value as a parameter. Second, it calculates the strong rules as the predicate and the consequent on the basis of confidence value which is presented as a parameter. 
The process can be represented in mathematical terms as: $I=\left\{i_{1}, i_{2}, \ldots, i_{n}\right\}$ and it shows all the elements. On the other hand, all the transactions in the data set are represented as $T=\left\{t_{1}, t_{2}, \ldots\right.$, $\left.t_{n}\right\}$. In this case, an item set having zero or more than zero element will be a sub-set of $X$. Then the number of an item set is stated as $\delta(X)=\left|\left\{t_{i} \mid X \subseteq t_{i}, t_{i} \in T\right\}\right|$. An association rule with $X$ $\cap Y=\varnothing$ is described as $X$ (predicate) $\rightarrow$ Y (consequent) (Lai \& Cerpa, 2001). According to these descriptions, the support value of an association rule in a data containing $\mathrm{N}$ number of transactions is shown in Equation 2 and confidence value is shown in Equation 3. It would be more appropriate to take into account the confidence value rather than the support value in interpreting the usefulness of the rules determined. This is because consequent is calculated according to the frequency of predicate in calculating the confidence value. In other words, posterior probability is taken into consideration here. Yet, there is no such computation throughout the calculation of support value. As a result of this fact, important and useful rules having relatively lower support values can be identified. This situation is illustrated in details in Tables 1 and 2 below.

$$
\begin{gathered}
\text { Support, } \mathrm{s}(\mathrm{X} \rightarrow \mathrm{Y})=\frac{\delta(\mathrm{X} \cup \mathrm{Y})}{\mathrm{N}} \\
\text { Confidence, } \mathrm{g}(\mathrm{X} \rightarrow \mathrm{Y})=\frac{\delta(\mathrm{X} \cup \mathrm{Y})}{\delta(\mathrm{X})}
\end{gathered}
$$

Apriori algorithm functions with discrete data. Since the data set used in the study was numeric, GRI algorithm given in SPSS Clementine 12 data mining software was used. The GRI algorithm was preferred because it adopts Apriori as a principle and because it can also accept numerical data. Table 1 shows the calculations about the support value and the confidence value used.

In order to apply GRI algorithm over the dataset, we first loaded the data from a Microsoft Excel file into SPSS Clementine 12 software. Next, we have picked the GRI algorithm and make it run over the dataset by defining minimum support and confidence scores. Upon the model construction, generated rules were listed according to the confidence value in descending order. At this stage, we have selected the robust rules.

\begin{tabular}{|c|c|c|c|}
\hline TID & Items & Support = Observation / Total Records & $\begin{array}{l}\text { When } \mathrm{X} \rightarrow \mathrm{Y}, \text { Confidence }= \\
\text { Observation }(\mathrm{Y}) / \text { Observation }(\mathrm{X})\end{array}$ \\
\hline 1 & $\mathrm{AB}$ & \multirow{6}{*}{$\begin{array}{l}\text { Total Records }=6 \\
\text { Support }\{B C\}=3 / 6=50 \% \\
\text { Support }\{A D\}=3 / 6=50 \% \\
\text { Support }\{A B D\}=2 / 6=33.3 \% \\
\text { Support }\{B C D\}=2 / 6=33.3 \%\end{array}$} & \multirow{6}{*}{$\begin{array}{l}\text { Confidence }\{B \rightarrow C\}=3 / 5=60 \\
\% \\
\text { Confidence }\{A \rightarrow C\}=2 / 4=50 \% \\
\text { Confidence }\{A B \rightarrow C\}=1 / 3= \\
33.3 \% \\
\text { Confidence }\{A B \rightarrow D\}=2 / 3= \\
66.7 \%\end{array}$} \\
\hline 2 & $\mathrm{ABCD}$ & & \\
\hline 3 & $\mathrm{BCD}$ & & \\
\hline 4 & $\mathrm{BC}$ & & \\
\hline 5 & $\mathrm{ACD}$ & & \\
\hline 6 & $\mathrm{ABD}$ & & \\
\hline
\end{tabular}

Table 1. Support and confidence value computation for a sample dataset

As is seen from Table $1, T_{i} \in\{A, B, C, D\}$ and it includes different elements. Six item sets in total are shown to exemplify what has been stated. Different associations of the elements are shown in second column of the table. Accordingly, example association rules are shown in the column on the right hand side. By considering the example item sets in the second column, various support and confidence values were calculated in third and fourth columns respectively. Since the item set $\{B, C\}$ appeared three times, the support value has been computed as $3 / 6=50 \%$. However, if one examines the rule "B $\rightarrow C$ ", it can be easily seen that the item $\{B\}$, which was the predicate of the rule, appears only 5 times along with the item $\{B, C\}$, which appears only 3 
times. Consequently, the confidence values for the rule " $B \rightarrow C$ " has been calculated as $3 / 5=60 \%$. The study considers cluster analysis and association rules analyses together. While the individuals taking part in the questionnaire were divided into 3 groups with the help of clustering and thus the differences were analysed, patterns frequently observed in teachers' and prospective teachers' views were revealed via association rules. This study analysed the variables shown in Table 2 and the properties related to those variables in clustering method.

Table 2. Properties of variables constituting the data set

\begin{tabular}{|c|c|c|}
\hline Name of the Attribute & Type & Values and Number of Distributions \\
\hline Type of participant & Discrete & Prospective teachers $(191-65.6 \%)$, teachers $(100-34.4 \%)$ \\
\hline Gender & Discrete & Male $(97-33.3 \%)$, Female $(194-66.7 \%)$ \\
\hline $\begin{array}{l}\text { Having taken a course related } \\
\text { with ICT before }\end{array}$ & Discrete & Yes $(269-92.4 \%), \operatorname{No}(22-7.6 \%)$ \\
\hline $\begin{array}{l}\text { Having a computer of one's } \\
\text { own }\end{array}$ & Discrete & Yes $(268-92 \%)$, No $(23-8 \%)$ \\
\hline Computer using skills & Discrete & $\begin{array}{l}\text { Very good }(52-17.8 \%), \text { Good }(132-45.3 \%), \text { Medium } \\
(93-31.9 \%), \text { Low }(10-3.4 \%), \text { Very low }(4-1.3 \%)\end{array}$ \\
\hline $\begin{array}{l}\text { Length of computer use } \\
\text { (daily) }\end{array}$ & Discrete & $\begin{array}{l}\text { More than } 7 \text { hours }(13-4.4 \%), 5-6 \text { hours }(38-13 \%), 3-4 \\
\text { hours }(88-30.2 \%) \text {,less than } 2 \text { hours }(145-49.8 \%) \text {, Not } \\
\text { any }(6-2 \%)\end{array}$ \\
\hline Total positive values in views & Continuous & Min: 26, Max: 72, Mean: 55.1, SD: 7.037 \\
\hline
\end{tabular}

While qualities such as the type of participants, gender, having a computer of one's own and having taken a course related with ICT before are binary data; length of computer use and computer using skills exist as nominal data. Whereas the mean was 55.1 for total positive values in views, standard deviation was 7.037. In association rules analysis - which was done in addition to cluster analysis - the data collected through a scale containing various views were analysed. Minimum support was found to be $32 \%$ and minimum confidence was found to be $85 \%$ in GRI analysis-which was done for association rules in this study.

\section{RESULT and DISCUSSION}

The findings obtained in this study are presented under two headings as findings obtained from cluster analysis and findings obtained from association rules analysis. While differences between natural groups formed by considering prospective teachers and teachers together were included in findings obtained from cluster analysis, views held by teachers and prospective teachers were considered separately in findings obtained from association rules analysis.

\subsection{Results and Discussion for Clustering Analysis}

Cluster analysis was carried out on data collected from teachers and prospective teachers. Values 2, 3 and 4 were tried in determining the clusters regarding $\mathrm{k}$ as the number of clusters, and 3which was observed to be the most discriminative- was selected. The properties of clusters arising as a result of cluster analysis are shown in Table 3.

An examination of Table 3 makes it clear that the biggest cluster in terms of computer using skills and length of computer usage is Cluster 1 with 144 individuals in it- which was followed by Cluster 2 and Cluster 3. If we examine the details of Cluster 1, it was found that the cluster is composed of prospective teachers and that the distribution of the number of female and male participants is in balance. It is clear that Cluster 1 is the most active cluster with percentages of total number of individuals in categories of "good" and "very good" in computer using skills and with percentages of using computers more than 3 hours daily. Accordingly, the individuals in Cluster 1-94.4\% of whom had taken a course in computer- spent longer hours on computer than 
the ones in the other clusters. As a result of this, the individuals in Cluster 1 had higher computer using skills than the ones in the other two clusters. This was a finding supportive of the conclusion Seferoğlu, Akbıyık and Bulut (2008) reached indicating prospective teachers used information technologies at higher levels than teachers did. An examination of the findings for the clusters demonstrated that the length of computer use had positive correlations with computer using skills. Similar conclusions were reached in studies investigating the use of technology in education (Yanık, 2010).

Table 3. Clustering results for teachers and prospective teachers

\begin{tabular}{|c|c|c|c|}
\hline Clusters & Cluster 1 & Cluster 2 & Cluster 3 \\
\hline Population & 144 & 67 & 80 \\
\hline Type of user & $\begin{array}{l}\text { Prospective teachers: } \\
144(100.0 \%) \\
\text { Teachers:0 }(0 \%)\end{array}$ & $\begin{array}{l}\text { Prospective teachers: } \\
0(0 \%) \\
\text { Teachers } 67(100 \%)\end{array}$ & $\begin{array}{l}\text { Prospective teachers: } 47 \\
(58.75 \%) \\
\text { Teachers: } 33(41.25 \%)\end{array}$ \\
\hline Gender & $\begin{array}{l}\text { Female: } 75(52.08 \%) \\
\text { Male: } 69(47.92 \%)\end{array}$ & $\begin{array}{l}\text { Female: } 56(83.58 \%) \\
\text { Male: } 11(16.4 \%)\end{array}$ & $\begin{array}{l}\text { Female: } 63(78.75 \%) \\
\text { Male: } 17(11.25 \%)\end{array}$ \\
\hline $\begin{array}{l}\text { Length of } \\
\text { computer use }\end{array}$ & $\begin{array}{l}\text { None: } 4(2.7 \%) \\
\text { Less than } 2 \text { hours: } 42 \\
(29.16 \%) \\
\text { 3-4 hours: } 61(42.36 \%) \\
\text { 5-6 hours: } 27(18.75 \%) \\
\text { More than } 7 \text { hours: } 10 \\
(6.9 \%)\end{array}$ & $\begin{array}{l}\text { None: } 0(0 \%) \\
\text { Less than } 2 \text { hours } 29 \\
(43.2 \%) \\
\text { 3-4 hours } 26(38.8 \%) \\
5-6 \text { hours:9 }(13.43 \%) \\
\text { More than } 7 \text { hours:3 } \\
(4.47 \%)\end{array}$ & $\begin{array}{l}\text { None: } 3(3.75 \%) \\
\text { Less than } 2 \text { hours: } 74 \\
(92.5 \%) \\
\text { 3-4 hours: } 1(1.25 \%) \\
\text { 5-6 hours: } 2(2.5 \%) \\
\text { More than } 7 \text { hours:0 }(0 \%)\end{array}$ \\
\hline $\begin{array}{l}\text { Having a } \\
\text { computer }\end{array}$ & $\begin{array}{l}\text { Yes } 138(95.8 \%) \\
\text { No: } 6(4.2 \%)\end{array}$ & $\begin{array}{l}\text { Yes: } 65(97.01 \%) \\
\text { No: } 2(2.99 \%)\end{array}$ & $\begin{array}{l}\text { Yes: } 65(81.25 \%) \\
\text { No: } 12(18.75 \%)\end{array}$ \\
\hline $\begin{array}{l}\text { Having taken } \\
\text { a course } \\
\text { related with } \\
\text { ICT before }\end{array}$ & $\begin{array}{l}\text { Yes: } 136(94.4 \%) \\
\text { No: } 8(5.6 \%)\end{array}$ & $\begin{array}{l}\text { Yes: } 60(89.55 \%) \\
\text { No: } 7(10.45 \%)\end{array}$ & $\begin{array}{l}\text { Yes: } 73(91.25 \%) \\
\text { No: } 6(8.75 \%)\end{array}$ \\
\hline $\begin{array}{l}\text { Computer } \\
\text { using skills }\end{array}$ & $\begin{array}{l}\text { Very low: } 2(1.38 \%) \\
\text { Low: } 2(1.38 \%) \\
\text { Medium: } 9(6.25 \%) \\
\text { Good: } 92(63.8 \%) \\
\text { Very good:39 }(27.08 \%)\end{array}$ & $\begin{array}{l}\text { Very low: } 2(2.9 \%) \\
\text { Low: } 6(8.9 \%) \\
\text { Medium: } 6(8.9 \%) \\
\text { Good: } 40(59.7 \%) \\
\text { Very good: } 13(19.4 \%)\end{array}$ & $\begin{array}{l}\text { Very low: } 0(0 \%) \\
\text { Low: } 2(2.5 \%) \\
\text { Medium: } 78(97.5 \%) \\
\text { Good: } 0(0 \%) \\
\text { Very good: } 0(\%)\end{array}$ \\
\hline $\begin{array}{l}\text { View scores } \\
\text { in total }\end{array}$ & $\begin{array}{l}\text { Average: } 54.97 \\
\text { SD: } 7.25\end{array}$ & $\begin{array}{l}\text { Average: } 57.27 \\
\text { SD: } 7.36\end{array}$ & $\begin{array}{l}\text { Average: } 53.51 \\
\text { SD: } 5.90\end{array}$ \\
\hline
\end{tabular}

As is evident from Table 3, Cluster 2 was composed of teachers only. The participants in this group were al practicing teachers and they were mostly (83.8\%) female. 57\% of the individuals in this group- who had similarities with Cluster 1 in the length of computer use and in computer using skills- used computers more than 3 hours a day. In addition to that, the majority of them (78.2\%) said that they considered themselves to be at medium level or above in terms of computer using skills. Besides, Cluster 2 was found to be the group holding the most positive views about using ICT instruments in the classroom. This was a finding consistent with the finding that teachers developed positive attitudes towards technological developments and educational technologies obtained in Halderman (1992), Çă̆ıltay et al. (2001) and Kurtdede Fidan (2008). Computer using skills of the individuals in Cluster 2 who were practicing teachers might have positively influenced the views of those individuals about using ICT instruments. The evidence for this may be the differences observed between Cluster 2 and Cluster 3. Although the numerical difference was not big between positive views, positive contributions were observed generally. It was also remarkable that the percentage of having a computer was higher in this cluster- of which the members were practicing teachers. Thus, it was thought that owning a computer might 
affect teachers in having positive views about using ICT instruments. This was a result similar to the one found in a study conducted by Deniz and Köse (2003) with the participation of prospective teachers.

Interpreting the findings for Cluster 1 along with the ones for Cluster 2, it was concluded that owning a computer had direct influence on computer using skills and length of computer use. This mirrors the conclusion reached by Kıyıcı (2008) that for prospective teachers possessing a computer is correlated with computer literacy. This current study is also supportive of the conclusions reached by Çavuş and Gökdaş (2006) that the level of computer usage skills of prospective teachers who do not have computer is inadequate, by Kuşkaya Mumcu and Koçak Usluel (2004) that the $81,8 \%$ of teachers who have own computer stated that they use it and also by Winnans and Brown (1992) that elementary teachers' having own computer or using them for personal reasons at home or school is seen as a factor that affect teachers' use of the computer. First, very few teachers themselves. Cluster 3 containing 80 individuals was the group with the lowest values in terms of computer using skills and the length of computer use. The group was composed of prospective teachers as well as teachers and had shorter length of computer use. The great majority (97.5\%) of the individuals in Cluster 3 said they had medium level of computer using skills. They (more than 96\%) were also found to spend less than 2 hours using computer daily. Approximately one fifth of the group- of which the majority $(81.25 \%)$ was female- did not have a computer of their own. Cluster 3- which was well behind the other clusters in terms of information and communication technologies- ranked the last in positive views on using ICT instruments in the classroom.

The clustering study reveals some other interesting findings regarding the relation between gender and computer using skills. If the properties of participant distributions of each cluster are carefully investigated it can be seen that the male participants in especially cluster 1 constitute much larger proportion compared to other clusters. Moreover, regarding the cluster 1 results, it has been found that this cluster involves the highest computer skill abilities when good and very good scores are summed up. If the proportions of the male and female participants are reviewed, it can be also seen that, the cluster 1 has much larger proportion of men compared to other clusters. Combination of these two findings supports that technology is considered as a genderspecific issue related to men (Lewis, 1999; Kuşkaya Mumcu \& Koçak Usluel, 2004). One another finding regarding to the length of computer usage duration, the cluster 1 also involves the longest duration if the values are investigated. Furthermore, the cluster 1 has been solely composed of prospective teachers. However, it is noteworthy that, the findings of some of the studies in the literature pointed out that prospective teachers 'attitudes about computer usage does not differ in terms of gender (Deniz \& Köse, 2003; Gerçek et al., 2006; Çoklar, 2008).

\subsection{Results and Discussion about Association Rules Mining}

The data collected from teachers and prospective teachers was then subjected to the association rules mining. The information written in "Consequent" column is in cause and effect relation with the information written in "Predicate" column along with the "support" and "confidence" scores. Following the analysis, the views held by prospective teachers are shown in Table 4. According to Table 4, 95.52\% of the prospective teachers stating that ICT instruments added variety into teaching-learning process and that those instruments ensure that students focused their attention on lessons said that making use of ICT instruments would increase students' participation in classes. This finding was similar to the one obtained by Güngör and Aşkar (2004). The prospective teachers participating in the above mentioned study said that ICT instruments added variety into classes, as a result, it increased interest and efforts in classes and that classes gained continuity instead of being restricted into class hours. Besides, $90.77 \%$ of the participants who stated that ICT instruments ensures that students focused their attention on lessons, that learning with ICT instruments was more effective and that ICT instruments enable to concretize 
what students learn in the classroom also, stated that students' effective use of ICT instruments would influence their achievement in positive ways. This finding was similar to that of Sadi, Şekerci, Kurban, Topu, Demirel, Tosun, Demirci, \& Göktaş (2008).

Table 4. Some of the results for association rules for prospective teachers

\begin{tabular}{|c|c|c|c|}
\hline Predicate & Consequent & Support & Confidence \\
\hline $\begin{array}{l}\text { ICT instruments add variety } \\
\text { into teaching-learning } \\
\text { processes= I agree, Using } \\
\text { ICT instrument in classes } \\
\text { ensures that students focus } \\
\text { their attention on lessons" = } \\
\text { I agree }\end{array}$ & $\begin{array}{l}\text { I think that making use of } \\
\text { ICT instruments } \\
\text { increases students' } \\
\text { participation in classes = } \\
\text { I agree }\end{array}$ & $35.08 \%$ & $95.52 \%$ \\
\hline $\begin{array}{l}\text { Using ICT instrument in } \\
\text { classes ensures that students } \\
\text { focus their attention on } \\
\text { lessons = I agree, ICT } \\
\text { instruments ensure that } \\
\text { students concretize what } \\
\text { they have learnt in the } \\
\text { classroom = I agree }\end{array}$ & $\begin{array}{l}\text { Students' effective use of } \\
\text { ICT instruments } \\
\text { influences their } \\
\text { achievement in positive } \\
\text { ways ICT = I agree }\end{array}$ & $34.03 \%$ & $90.77 \%$ \\
\hline $\begin{array}{l}\text { Learning is more effective } \\
\text { in schools equipped with } \\
\text { ICT= I agree, ICT } \\
\text { instruments ensure that } \\
\text { students concretize what } \\
\text { they have learnt in the } \\
\text { classroom = I agree }\end{array}$ & $\begin{array}{l}\text { Students' effective use of } \\
\text { ICT instruments } \\
\text { influences their } \\
\text { achievement in positive } \\
\text { ways ICT = I agree }\end{array}$ & $41.36 \%$ & $86.08 \%$ \\
\hline $\begin{array}{l}\text { ICT instruments ensure that } \\
\text { students concretize what } \\
\text { they have learnt in the } \\
\text { classroom = I agree, View } \\
\text { scores in total >52.5 }\end{array}$ & $\begin{array}{l}\text { Students' effective use of } \\
\text { ICT instruments } \\
\text { influences their } \\
\text { achievement in positive } \\
\text { way ICT= I agree }\end{array}$ & $35.6 \%$ & $86.76 \%$ \\
\hline $\begin{array}{l}\text { Learning is more effective } \\
\text { in schools equipped with } \\
\text { ICT= I agree, Using ICT } \\
\text { instrument in classes } \\
\text { ensures that students focus } \\
\text { their attention on lessons = I } \\
\text { agree }\end{array}$ & $\begin{array}{l}\text { Students' effective use of } \\
\text { ICT instruments } \\
\text { influences their } \\
\text { achievement in positive } \\
\text { ways ICT= I agree }\end{array}$ & $32.98 \%$ & $85.71 \%$ \\
\hline
\end{tabular}

The majority of the prospective teachers taking part in the above mentioned study said that use of technology made learning permanent and ensured better comprehension and that it increased the quality of education and motivation in classes. In addition to that, nel, Evrekli and Balım (2011) also reached similar conclusions. Accordingly, the prospective teachers pointed out that using technology would be beneficial in science and technology teaching and that it could also have such effects on students as ensuring audio and visual learning, increasing interest and attention, facilitating learning, concretizing abstract concepts and increasing retention in 
learning. Also, the finding that prospective teachers' views on the use of technology are positive in general is also available in the literature. Following the interviews with prospective teachers Yavuz and Coşkun (2008) and Yılmaz, Ulucan and Pehlivan (2010) found that prospective teachers held positive views on the use of technology; and Usta and Korkmaz (2010) found that they had positive perception in this respect and Özgen and Obay (2008) found that they had positive attitudes. In addition to the finding that prospective teachers had positive views on the use of ICT, the data collected from teachers were put to association rules analysis. Following the analysis, the teachers' views are shown in Table 5.

Table 5. Some of the results for association rules for teachers

\begin{tabular}{llllll}
\hline Predicate & Consequent & & Support & Confidence \\
\hline ICT instruments add variety into & I think that making use of ICT & $32 \%$ & $100 \%$ \\
teaching-learning processes = I & instruments increases students' & & \\
agree, View scores in total> 50.5 & participation in classes = I totally agree & &
\end{tabular}

\begin{tabular}{|c|c|c|c|}
\hline $\begin{array}{l}\text { Using ICT instrument in classes } \\
\text { ensures that students focus their } \\
\text { attention on lessons = I totally } \\
\text { agree }\end{array}$ & $\begin{array}{l}\text { I think that making use of ICT } \\
\text { instruments increases students' } \\
\text { participation in classes = I totally agree }\end{array}$ & $32 \%$ & $96.88 \%$ \\
\hline $\begin{array}{l}\text { Using ICT instrument in classes } \\
\text { ensures that students focus their } \\
\text { attention on lessons = I agree }\end{array}$ & $\begin{array}{l}\begin{array}{l}\text { Students' effective use of ICT } \\
\text { instruments influences } \\
\text { achievement in positive ways }\end{array}=\text { I agree } \\
\text { their }\end{array}$ & $33 \%$ & $93.94 \%$ \\
\hline $\begin{array}{l}\text { ICT instruments add variety into } \\
\text { teaching-learning processes= I } \\
\text { agree, Using ICT instrument in } \\
\text { classes ensures that students focus } \\
\text { their attention on lessons = I agree, } \\
\text { I think that making use of ICT } \\
\text { instruments increases students' } \\
\text { participation in classes = I agree }\end{array}$ & $\begin{array}{l}\text { Learning is more effective in schools } \\
\text { equipped with } \mathrm{ICT}=\mathrm{I} \text { agree }\end{array}$ & $33 \%$ & $90.91 \%$ \\
\hline $\begin{array}{l}\text { ICT instruments add variety into } \\
\text { teaching-learning processes = I } \\
\text { agree }\end{array}$ & $\begin{array}{l}\text { Using ICT instrument in classes ensures } \\
\text { that students focus their attention on } \\
\text { lessons = I agree }\end{array}$ & $41 \%$ & $85.37 \%$ \\
\hline
\end{tabular}

According to Table 5, teachers stating that ICT instruments added variety into the teachinglearning processes also said that making use of ICT instruments would increase students' participation in classes. This was a finding parallel to the one obtained in Ertmer et al (2012). Accordingly, the teachers participating in the study said that technology enriched curriculum and thus more active student participation was ensured. Tekinarslan (2007) also pointed out that using technology in teaching environments would result in richness and thus would ensure students to participate more actively in classes. $96.88 \%$ of teachers stating that using ICT instruments ensured that students focused their attention on lessons also said that making use of ICT instruments would increase students' participation in classes. This finding was supportive of the one obtained in Kurtdede Fidan (2008) because the study concluded that education performed by using equipment and aids increased students' interest in classes and that it ensured active participation. In addition to this finding of research, $93.44 \%$ of the teachers stating that ICT instruments enabled students to focus their attention on lessons and that they concretized what students have learnt in classes also said that students' effective use of ICT instruments would influence their achievement in positive ways. The views that ICT enables students to focus their attention on lessons and thus increase achievement (Gu, 2017), that it increases achievement by increasing participation in classes (Yanpar Yelken, 2012), that it affects achievement in positive 
ways by giving the impression that one uses real equipment (Çelik, 2007) which are reported in the literature are all in parallel to this finding of this study. Apart from that, teachers who had taken part in the study conducted by Üredi, Akbaşlı and Ulum (2016) also pointed out that ICT concretized what students had learned, that it attracted students' attention and that it brought about effective and permanent learning. At the same time, $90.91 \%$ of the teachers thinking that ICT instruments added variety into teaching-learning processes, that they enabled students to focus their attention on lessons and that they would increase students' participation in classes also stated that learning was more effective in schools equipped with ICT. Studies available in the literature suggest that ICT makes learning effective by enriching the teaching-learning process (Baytekin, 2004; Yanpar, Yelken 2012; Üredi, Akbaşlı \& Ulum, 2016). Additionally, the study of Kurtdede Fidan (2008) made out that teachers believed that using equipment and aids in teaching learning process sparked students' interest towards the lesson and ensure both students' learning while having fun and participating more actively. Also teachers participated to the the same study stated that lessons were more effective and efficient in this way. Furthermore, having stated that ICT instruments added variety into the teaching-learning processes, teachers also stated that ICT instruments ensured that students focused their attention on lessons. Russell, Bebell, O'Dwyer and O'Connor (2003) pointed out that experienced teachers used technology to attract their students' attention.

\section{CONCLUSION and RECOMMENDATIONS}

Teaching environments in which information and communication technologies are used, aim to put students into the center and to actualize learning in the best way. Concerning the variables for teachers and prospective teachers and concerning their views on the use of ICT instruments, cluster analysis and association rules mining have significant advantages for exploring the patterns and relations hidden in raw data. Thus, 3 clusters were distinguished with cluster analysis. Views on the use of ICT instruments and many other properties (such as having a computer of one's own, gender, etc.) that those views could influence were analyzed in those clusters. The cluster having the highest level of computer using skills and the length of daily computer use was Cluster 1, which was composed of only prospective teachers. Considering the same properties, Cluster 2 followed Cluster 1, and Cluster 3- which was composed of teachers and prospective teachers- ranked the last. In this context, prospective teachers considered themselves as being more proficient than practicing teachers in computer using skills. In addition to that, teachers were found to be the group having the most positive views on the use of ICT instruments in the classroom setting. On interpreting the findings concerning teachers along with the findings concerning prospective teachers, it was concluded that having a computer of one's own had linear correlations with computer using skills and with the length of computer use. It was also found in cluster analysis that the number of male prospective teachers having computer using skills is much more than the female prospective teachers' accordin to the properties of cluster 1 when compared to other clusters.

The data collected in relation to the views of teachers and prospective teachers were given to association rules analysis in addition to cluster analysis. The results of association rules analysis indicated that ICT instruments added variety into the teaching-learning process, that they helped students to focus their attention on lessons and that making use of ICT instruments would also increase students' participation in classes. It was remarkable that the rules having high confidence values (95\% and above) obtained from both teachers and prospective teachers touched on the same points. Motivation to use ICT instruments in classrooms can be raised by emphasizing those properties-which teachers and prospective teachers stressed- in teacher training and in in-service training. 


\section{Acknowledgement}

This manuscript is the extended version of the papers presented in 4th International Eurasian Educational Research Congress and 13 th International Conference on ICT in The Education of the Balkan Countries.

\section{ORCID}

Ozge Can Aran (iD) https://orcid.org/0000-0003-3229-4325

Ahmet Selman Bozkir (iD http://orcid.org/0000-0003-4305-7800

Bilge Gök (iD https://orcid.org/0000-0002-1548-164X

Esed Yagci (iD https://orcid.org/0000-0002-5418-1172

\section{REFERENCES}

Agrawal, R., \& Srikant. R. (1994). Fast algorithms for mining association rules in large databases. Paper presented at 20th International Conference on Very Large Data Bases, San Fransisco.

Akkoyunlu, B., \& Yılmaz, M. (2005). Türetimci çoklu ortam öğrenme kuramı [Generative theory of multimedia learning]. Hacettepe University Journal of Education, 28, pp.9-18.

Bayazıt, A., \& Seferoğlu. S. S. (2009). Türkiye' deki teknoloji politikalarında eğitimin yeri ve öğretmen yetiştirme politikaları. 12. Bilişim Teknolojileri Işı ğında Eğitim Kongresi (BTIE’2009) Bildiriler Kitabı. Ankara: Türkiye Bilişim Derneği.

Baytekin, Ç. (2004). Öğrenme-öğretme teknikleri ve materyal geliştirme. Ankara: Anı Yayıncilik.

Borich, G. D. (2014). E tkili öğretim yöntemleri. (B. Acat, Trans.). Ankara: Nobel Yayınları.

Bozkir, A. S., Gök, B., \& Sezer, E. (2008). Ü niversite öğrencilerinin interneti eğitimsel amaçlar için kullanmalarını etkileyen faktörlerin veri madenciliği yöntemleriyle tespiti. Paper presented at Bilimde Modern Yöntemler Sempozyumu, Osmangazi Üniversitesi, Eskişehir.

Bozkir, A. S., Gök, B. \& Sezer, E. (2009). Determination of the factors influencing student's success in student selection examination (OSS) via data mining techniques. Paper presented at $5^{\text {th }}$ Uluslararası leri Teknolojiler Sempozyumu, Karabük.

Buabeng-Andoh, G. (2012). Factors influencing teachers' adoption and integration of information and communication technology into teaching: A review of the literature. International Journal of Education and Development Using Information and Communication Technology (IJEDICT), 8(1), pp.136-155.

Büyüköztürk, Ş. (2006). Sosyal bilimler için veri analizi el kitabı. Ankara: Pegem A Yayıncılık.

Bybee, R. W., \& Loucks-Horsley, S. (2000). Advancing technology education: The role of professional development, The Technology Teacher, 60(2), pp.31-34.

Can Aran, Ö. \& Senemoğlu, N. (2014). Disiplinli zihin özellikleri açısından fen eğitiminin incelenmesi [An investigation of science education in terms of disciplined mind characteristics]. Hacettepe University Journal of Education, 29(4), pp.46-59.

Can Aran, Ö., Derman, ., \& Yağc1, E. (2016). Pre-service science and mathematics teachers' thoughts about technology. Universal Journal of Educational Research, 4(3), pp.501-510.

Çağıltay, K., Çakıroğlu, J., Çağıltay, N. \& Çakıroğlu, E. (2001). Öğretimde bilgisayar kullanimina ilişkin öğretmen görüşleri [Teachers' perspectives about the use of computers in education]. Hacettepe University Journal of Education, 21, pp.19-18.

Çavuş, H. \& Gökdaş, . (2006). Eğitim fakültesi’nde öğrenim gören öğrencilerin internetten yararlanma nedenleri ve kazanımları [Education faculty students' benefiting reasons from internet and their gains]. Yuzuncu Yil University Journal of Education, 3(2), pp. 56-78.

Çelik, L. (2007). Öğretim materyallerinin hazırlanması ve seçimi. In Öğretim teknolojileri ve materyal tasarımı edited by Özcan Demirel ve Eralp Altun. Ankara: Pegem Yayınları. 
Çoklar, A. N. (2008). Öğretmen adaylarının eğitim teknolojisi standartları ile ilgili özyeterliklerinin belirlenmesi [Assessing the self-efficacy of teacher candidates concerning the educational technology standards]. Doctoral dissertation, Anadolu University, Eskişehir.

Deniz, L \& Köse, H. (2003). Öğretmen adaylarının bilgisayar yaşantıları ve bilgisayar tutumları arasındaki ilişkiler [The relationship between computer attitudes and computer experiences of student teachers]. Marmara Üniversitesi Atatürk Eğitim Fakültesi Eğitim Bilimleri Dergisi / Journal of Educational Sciences, 18, pp. 39-64.

Ertmer, P. A, Ottenbreit-Leftwich, A., Olgun, S., Sendurur, E., \& Sendurur, P. (2012). Teacher beliefs and technology integration practices: A critical relationship. Computers \& Education, 59(2), pp. 423-435.

Floyd, F. J., \& Widaman. K. F. (1995). Factor analysis in the development and refinement of clinical assessment instruments. Psychological Assessment, 7(3), pp. 286-199.

Gerçek, C., Köseoğlu, P., Yılmaz, M. \& Soran, H. (2006). Öğretmen adaylarının bilgisayar kullanımına yönelik tutumlarının çeşitli değişkenler açısından incelenmesi [An analyses of the attitudes of teacher candidates towards computer use]. Hacettepe University Journal of Education, 30, pp.130-139.

Güngör, C., \& Aşkar, P. (2004). E-öğrenmenin ve bilişsel stilin başarı ve internet öz-yeterlik algisı üzerindeki etkisi [The effects e-learning and cognitive style on achievement and perceived internet self-efficacy]. Hacettepe University Journal of Education, 27, pp. 116125.

Gu, P. (2017). Promoting students' motivation and use of srl strategies in online mathematics learning. Doctoral dissertation, University of Kansas.

Halderman, C. F. (1992). Design and evaluation of staff development program for technology in small schools. Doctoral dissertation, University of North Texas.

Haslaman, T., Mumcu, F. K. \& Usluel, Y. K. (2007). The integration of information and communication technologies in learning and teaching process: A lesson plan example. E ğitim ve Bilim, 32(146), pp.54.

Hill Less, K. (2003). Faculty adoption of computer technology for instruction in North Carolina community college system. Doctoral dissertation, East Tennessee State University.

nel, D., Evrekli, E., \& Balım, A. G. (2011). Öğretmen adaylarının fen ve teknoloji dersinde eğitim teknolojilerinin kullanılmasına ilişkin görüşleri [Views of science student teachers about the use of educational technologies in science and technology course]. Journal of Theoretical Educational Sciences, 4(2), pp.128-150.

Jenson, J., Lewis, B., \& Smith, R. (2002). No one way: Working models for teachers' professional development, Journal of Technology and Teacher Education, 10(4), pp.481496.

Karaman, M. K., \& Kurfallı. H. (2008). Sınıf öğretmenlerinin bilgi ve iletişim teknolojilerini öğretim amaçlı kullanım düzeyleri [Elementary school teacher's ICT usage level for instructional purposes]. Journal of Theoretical Educational Sciences, 1(2), pp.43-56.

Kıray, S. A., Gök, B., \& Bozkır, A. S. (2015). Identifying the factors affecting science and mathematics achievement using data mining methods. Journal of Education in Science, Environment and Health (JESEH), 1(1), pp.28-48.

Kıyıcı, M. (2008). Öğretmen adaylarının sayısal okuryazarlık düzeylerinin belirlenmesi [Identifying digital literacy level of teachers candidates]. Doctoral dissertation, Anadolu University, Eskişehir.

Kottler, E., \& Brookhart Costa, V. (2009). Integrate technology to enrich learning. In Secrets to success for science teachers (181-202). Corwin: Thousand Oaks. 
Kurtdede Fidan, N. (2008). lköğretimde araç gereç kullanımına ilişkin öğretmen görüşleri [Teachers' views with regard to the use of tools and materials in the primary level]. Journal of Theoretical Educational Sciences, 1(1), pp.48-61.

Kuşkaya Mumcu, F., \& Koçak Usluel, Y. (2004). Mesleki ve teknik okul öğretmenlerinin bilgisayar kullanımları ve engeller [Use of computers by vocational and technical schools' teachers and obstacles]. Hacettepe University Journal of Education, 26, pp.91-99.

Kürüm, D. (2016). Öğretim Materyallerinin Değerlendirilmesi. In Öğretim teknolojileri ve materyal tasarımı, edited by Kıymet Selvi. Ankara: Anı Yayıncılık.

Lai, K., \& Cerpa, N. (2001). Support vs confidence in association rule algorithms. Paper presented at Conference on the Chilean Operations Research Society, Chile.

Lewis, T. (1999). Research in technology education-some areas of need. Journal of Technology Education, 10(2), pp.41-56.

MacQueen, J. B. (1967). Some methods for classification and analysis of multivariate observations. Paper presented at $5^{\text {th }}$ Berkeley Symposium on Mathematical Statistics and Probability, Berkeley.

Moseley, D., Higgins, S., Bramald, R., Hardman, F., Miller, J., Mroz, M., Stout, J. (1999) Ways Forward with ICT: effective pedagogy using information and communications technology for literacy and numeracy in primary schools (Report No: ED458652). United Kingdom: Durham Univ. (England). Curriculum, Evaluation, and Management Centre. Retrieved from https://files.eric.ed.gov/fulltext/ED458652.pdf

Mumtaz, S. (2000). Factors affecting teachers' use of information and communications technology: A review of the literature. Journal of Information Technology for Teacher Education, 9(3), pp.319-342.

Özgen, K. \& Obay, M. (2008). O rtaöğretim matematik öğretmen adaylarının eğitim teknolojisine ilişkin tutumları. Paper presented at international educational technology conference (IETC), Anadolu Üniversitesi, Eskişehir.

P21 Partnership for 21st Century Learning. Available online: http://www.battelleforkids.org/networks/p21/frameworks-resources (accessed on 15 June 2019).

Russell, M., Bebell, D., O'Dwyer, L., \& O'Connor, K. (2003). Examining teacher technology use: Implications for preservice and inservice teacher preparation. Journal of Teacher Education, 54(4), pp. 97-310.

Sadi, S., Şekerci, A. R., Kurban, B., Topu, F. B., Demirel, T., Tosun, C., Demirci, T. \& Göktaş, Y. (2008). Öğretmen eğitiminde teknolojinin etkin kullanımı: Öğretim elemanları ve ögretmen adaylarının görüşleri [Effective technology use in teacher education: The views of faculty members and preservice teachers]. International Journal of Informatics Technologies, 1(3), pp. 43-49.

Seferoğlu, S. S., Akbıyı, C. \& Bulut, M. (2008). Elementary school teachers' and teacher candidates' opinions about computer use in learning/teaching process. Hacettepe University Journal of Education, 35, pp.273-283.

Sert, G., Kurtoglu, M., Akınc1, A., \& Seferoglu, S. S. (2012). Overview of research on teachers' technology usage: a content analysis study. Computers \& Education, 14(46), pp.1-8.

STEM (Science, Technology, Engineering and Math) (2019, May). Science, Technology, Engineering and Math: Education for Global Leadership. Retrieved from http://www.ed.gov/stem.

Tabachnick, B. G., \& Fidell, L. S. (2007). Using multivariate statistics (5 ${ }^{\text {th }}$ ed.). New York: Allyn and Bacon.

Tan, P.-N., Steinbach, M., \& Kumar, V. (2006). Introduction to data mining. Boston: Addison Wesley. 
Tekinarslan, E. (2007). Eğitimde internet kullanımı. In Öğretim teknolojileri ve materyal tasarımı, edited by Özcan Demirel and Eralp Altun. Ankara: Pegem Yayınları.

Tosun, N. (2006). Bilgisayar destekli ve bilgisayar temelli öğretim yöntemlerinin, öğrencilerin bilgisayar dersi başarısı ve bilgisayar kullanım tutumlarına etkisi: Trakya Üniversitesi E ğitim F akültesi örneği [The effects of computer assisted and computer based methods on the success of the students and the attitude of using computer in computer classes: A sample study at Education Faculty of Trakya"]. Master thesis, Trakya University, Edirne.

Usluel, Y. K., \& Aşkar, P. (2003). Teachers' stages at the innovation-decision process related to the use of computers: Changes in two years. Hacettepe University Journal of Education, 24, pp.119-128.

Usta, E., \& Korkmaz, Ö. (2010). Öğretmen adaylarının bilgisayar yeterlikleri ve teknoloji kullanımına ilişkin algıları ile öğretmenlik mesleğine yönelik tutumları [Pre-service teachers' computer competencies, perception of technology use and attitudes toward teaching career]. Journal of Human Sciences, 7(1), pp.1335-1349.

Üredi, L., Akbaşl1, S. \& Ulum, H. (2016). Investigating the primary school teachers' perspectives on the use of education platforms in teaching. Educational Research and Reviews, 11(15), pp.1432-1439.

Varner, S. V. (2003). Attitudes and perceptions of secondary language arts teachers towards computer technology and its use in curriculum and instruction. Doctoral dissertation, University of Alabama, Alabama.

Wicklein, R. C. (1993). Identifying critical issues and problems in technology education using a modified-delphi technique. Journal of Technology Education, 5(1), pp.54-71.

Winnans, C., \& Brown, D. S. (1992). Some factors affecting elementary teachers' use of the computer. Computers \& Education, 18(4), pp.301-309.

Yanık, C. (2010). Azeri öğretmen adaylarının bilgisayar okuryazarlık algıları ve internet kullanımına yönelik tutumları. In Uluslararası Öğretmen Yetiştirme Politikaları ve Sorunları Sempozyumu II Bildiri Kitabı (pp.191-201), Azerbaycan Devlet Pedagoji Üniversitesi, Bakü.

Yanpar Yelken, T. (2012). Öğretim teknolojileri ve materyal tasarımı. Ankara: Anı Yayıncılık. Yanpar, T. (2005). Öğretim teknolojileri ve materyal geliştirme. Ankara: Anı Yayıncılık.

Yavuz, S., \& Coşkun, E. A. (2008). Sınıf öğretmenliği öğrencilerinin eğitimde teknoloji kullanımına ilişkin tutum ve düşünceleri [Attitudes and perceptions of elementary teaching through the use of technology in education]. Hacettepe University Journal of Education, 34, pp.276-286.

Yllmaz, ., Ulucan, H. \& Pehlivan, S. (2010). The attitudes and thoughts of the students attending physical education teaching program about using technology in education. KEFAD, 11(1), pp.105-118. 